Tersedia online di: http://ejournal-balitbang.kkp.go.id/index.php/bawal
e-mail:bawal.puslitbangkan@ gmail.com
BAWAL WIDYA RISET PERIKANAN TANGKAP
Volume 11 Nomor 1 April 2019
p-ISSN: 1907-8226
e-ISSN: 2502-6410
BAWAL Nomor Akreditasi Kementerian RISTEKDIKTI: 21/E/KPT/2018

\title{
KUALITAS AIR, STATUS TROFIK DAN POTENSI PRODUKSI IKAN DANAU PANIAI, PAPUA
}

\section{WATER QUALITY, TROPHIC STATUS AND POTENTIAL OF FISH PRODUCTION IN LAKE PANIAI, PAPUA}

\author{
Samuel dan Yoga Candra Ditya \\ 'Balai Riset Perikanan Perairan Umum dan Penyuluhan Perikanan, \\ Teregistrasi I tanggal: 08 Mei 2018; Diterima setelah perbaikan tanggal: 26 Juni 2019; \\ Disetujui terbit tanggal: 08 Agustus 2019
}

\begin{abstract}
ABSTRAK
Danau Paniai termasuk tipe danau tektonik, berukuran besar dan telah dimanfaatkan sebagai tempat pariwisata, transfortasi, irigasi persawahan, sumber air minum dan perikanan tangkap. Aktivitas manusia disekitar danau juga berpengaruh terhadap kualitas, kesuburan dan produksi ikan perairan danau. Penelitian kualitas air, status trofik dan potensi produksi ikan bertujuan untuk mengevaluasi parameter kualitas air, tingkat kesuburan serta potensi produksi ikan perairan danau. Parameter diukur terdiri dari suhu, kedalaman, kecerahan, daya hantar listrik, $\mathrm{pH}$, oksigen, alkalinitas, amonia, nitrat, fosfat, total fosfor dan klorofil-a. Pengukuran dan pengambilan sampel air dilaksanakan pada bulan April, Juli dan Oktober 2016 di tujuh stasiun pengamatan. Hasil penelitian menunjukkan Danau Paniai mempunyai kualitas air yang baik untuk kehidupan ikan dan udang. Nilai indeks status trofik berdasarkan metode Carlson sebesar 49, mengklasifikasikan perairan pada tingkat kesuburan sedang. Angka potensi produksi ikan Danau Paniai ada sebesar 491 ton/tahun dan tingkat pemanfaatan sumberdaya ikan dan udang oleh nelayan ada sebesar 20,3 ton/tahun atau 4,13\% dari angka potensi produksi ikannya.
\end{abstract}

Kata Kunci: Kualitas air; status trofik; potensi produksi ikan; Danau Paniai

\section{ABSTRACT}

Lake Paniai is a tectonic lake, large in size and has been used as sites for tourism, transportation, rice irrigation, drinking water sources and capture fisheries. Human activities around the lake also affect the quality, trophics and fish production of lake waters. Research on water quality, trophic status and potential for fish production aimed to evaluate the parameters of water quality, trophic levels and fish production potential of lake waters. The measured parameters consisted of temperature, depth, transfarancy, conductivity, pH, oxygen, alkalinity, ammonia, nitrate, phosphate, total phosphorus and chlorophyll-a. Measurement and sampling of water were carried out in April, July and October 2016 at seven observation stations. The results showed that Lake Paniai had good water quality for fish and shrimp life. Trophic status index value of 49, classified waters at mesotrophic level. The number of fish production potential was 491 tons/year and the utilization levels of fish and shrimp resources by fishermen was 20.3 tons/year or $4.13 \%$ of the potential number of fish production.

\section{Keywords: Water quality; trophic status; potential of fish production; Lake Paniai}

\section{PENDAHULUAN}

Danau Paniai termasuk danau tektonik dan tergolong danau yang berukuran besar seluas 15.130 Ha dan berada di ketinggian 1.700 meter dpl. (Kementerian Pekerjaan Umum, 2012). Danau Paniai berpotensi menghasilkan produksi ikan guna mencukupi kebutuhan pangan akan ikan dan meningkatkan taraf hidup masyarakat sekitar danau. Danau Paniai tidak banyak menyimpan beragam jenis ikan air tawar. Ikan nila (Oreochromis niloticus), Korespondensi penulis:

e-mail:sam_asr@yahoo.co.id

Telp. 081354336031

DOI: http://dx.doi.org/10.15578/bawal.11.1.2019.19-31

Copyright (C) 2019, BAWAL WIDYA RISET PERIKANAN TANGKAP (BAWAL) mujair (Oreochromis mossambicus), mas/karper (Cyprinus carpio), belut (Monopterus albus) dan gabus (Channa striata) merupakan jenis ikan ekonomis penting yang dapat ditemui di danau ini. Selain itu di Danau Paniai juga terdapat jenis lobster air tawar (Cherax sp.) yang merupakan komoditi yang khas dan bernilai ekonomis tinggi. Aktifitas perikanan tangkap di Danau Paniai pada awalnya hanya bersifat untuk memenuhi kebutuhan pokok saja. Sekarang dengan bertambahnya kebutuhan akan protein ikan serta seiring dengan bertambahnya jumlah 
penduduk lokal dan pendatang, penangkapan semakin intensif dengan adanya aktifitas jual beli di pasar Enarotali, Kabupaten Paniai.

Geografis Papua didominasi oleh pegunungan dari barat hingga ke timur dan dengan jajaran pegunungan yang mencapai lebih dari 3000 meter di sepanjang pulau menyebabkan akses transportasi darat menjadi tidak mudah (Kartikasari, et al., 2012). Hal ini menyebabkan belum banyaknya data penelitian mengenai danau di Papua tidak terkecuali Danau Paniai. Penelitian pada sektor perikanan di perairan umum daratan Provinsi Papua sebagian baru pada ekosistem sungai dan rawa banjiran, sedangkan untuk Danau Paniai sendiri informasi penelitian masih terbatas. Ada banyak aktivitas di dalam maupun diluar perairan Danau Paniai, dan untuk sektor perikanan yang menonjol adalah perikanan tangkap. Di sekitar danau ada juga terdapat aktivitas manusia seperti di areal pasar, pemukiman dan aktivitas pembangunan jalan yang diperkirakan berpengaruh pada kualitas perairan danau. Kegiatan perikanan tangkap ataupun perikanan budidaya harus berdasarkan pada status trofik sebagai pedoman kelayakan lingkungan dan besaran potensi perairan sebagai tolak ukur pemanfaatan lahan perairan (Samuel \& Adiansyah, 2016).

Penelitian di Danau Paniai perlu dilakukan sebagai bentuk inisiasi yang diharapkan dapat memberikan kontribusi tentang kondisi perairan, status trofik dan potensi produksi ikan. Penelitian ini bertujuan untuk mengevaluasi kualitas air, status trofik dan juga besaran potensi produksi ikan di Danau Paniai yang diharapkan dapat menjadi nilai pembanding untuk penelitianpenelitian yang akan datang dan dapat digunakan untuk menilai kelayakan sumber daya air guna menunjang usaha perikanan yang nantinya berdampak pada pemenuhan kebutuhan pangan dan perekonomian masyarakat di Kabupaten Paniai.

\section{BAHANDANMETODE}

Penelitian dilakukan dengan metode pengambilan contoh sebanyak 3 kali yaitu bulan April mewakili puncak musim penghujan, Juli mewakili musim kemarau dan bulan Oktober 2016 mewakili musim hujan. Data yang dikumpulkan meliputi data primer dan sekunder. Pengumpulan data primer dilakukan secara langsung di lapangan pengamatan. Data sekunder diperoleh dari dinas perikanan setempat, serta hasil-hasil penelitian terdahulu yang relevan.

Lokasi pengambilan sampel ditetapkan berdasarkan purposive sampling methods dengan stasiun pengambilan contoh ditentukan berdasarkan keberadaan inlet, outlet, bagian tengah danau dan keterwakilan pemanfaatan zona sempadan danau / bagian litoral danau (Gambar 1). Pengukuran dan pengambilan sampel kualitas air di masing-masing stasiun penelitian dilakukan secara stratifikasi vertikal yaitu pada bagian permukaan, batas kecerahan dan dekat dasar perairan dengan parameter dan metoda pengamatan mengacu pada $\operatorname{APHA}(2005)$ dan Boyd (1988) (Tabel 1).

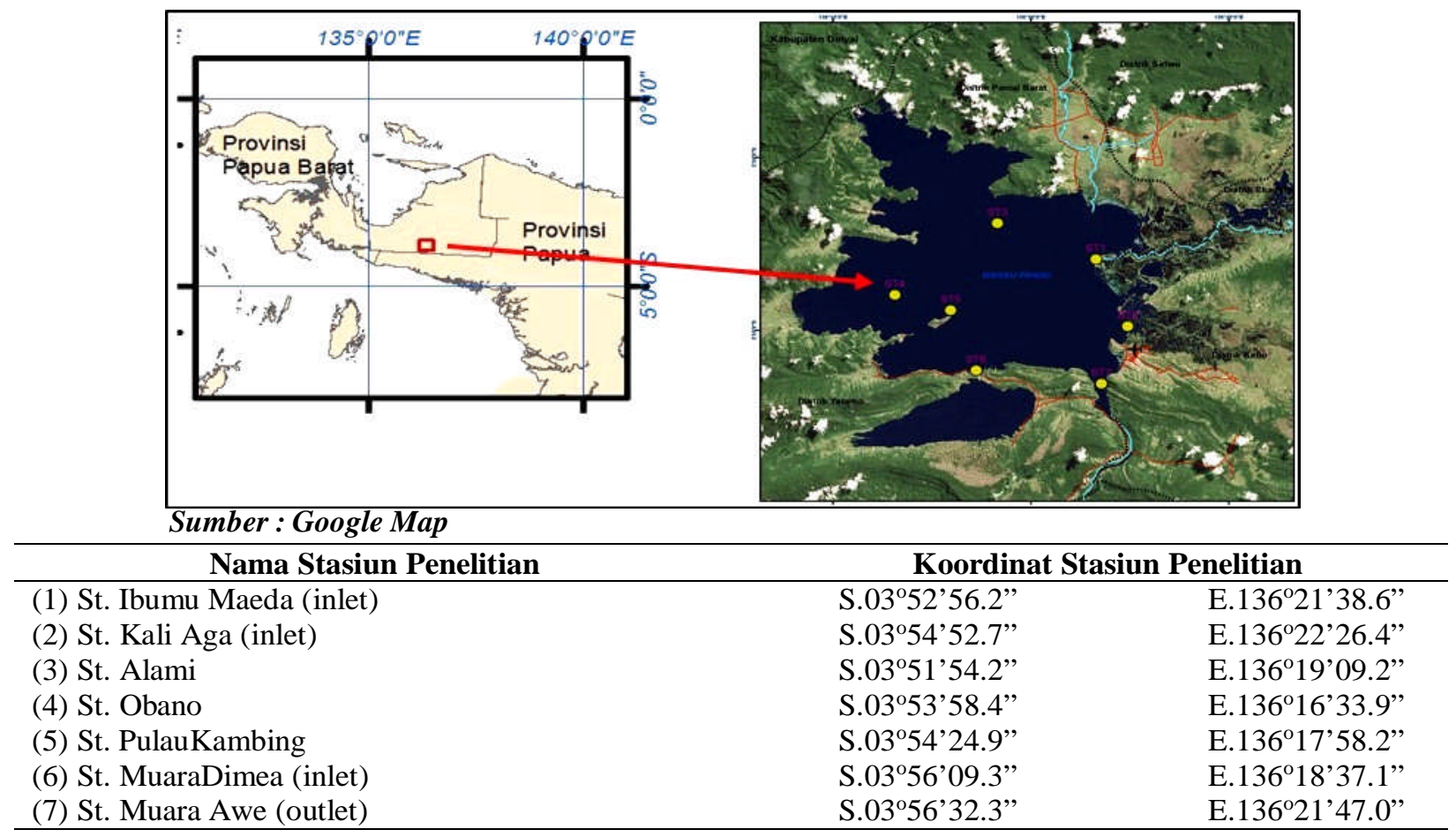

Gambar 1. Peta stasiun sampling kualitas air di Danau Paniai.

Figure 1. Map showing station of water quality in Lake Paniai. 
Tabel 1. Parameter kualitas air yang diukur, satuan, metode dan analisa

Table 1. Water quality parameters measured, units, methods and analysis

\begin{tabular}{clllll}
\hline No & $\begin{array}{l}\text { Parameter/ } \\
\text { Parameters }\end{array}$ & $\begin{array}{l}\text { Satuan/ } \\
\text { Unit }\end{array}$ & $\begin{array}{l}\text { Metode/ } \\
\text { Methods }\end{array}$ & $\begin{array}{l}\text { Analisa/ } \\
\text { Analysis }\end{array}$ & $\begin{array}{l}\text { Sumber/ } \\
\text { References }\end{array}$ \\
\hline 1 & Kedalaman & $\mathrm{meter}$ & Echodepth meter & insitu & APHA (2005) \\
2 & Kecerahan & $\mathrm{Cm}$ & Secchi Disk & insitu & APHA (2005) \\
3 & Temperatur/suhu & ${ }^{\circ} \mathrm{C}$ & YSI Proffesional & insitu & APHA (2005) \\
4 & Derajat Keasaman $(\mathrm{pH})$ & $\mathrm{unit}$ & YSI Proffesional & insitu & APHA (2005) \\
5 & Oksigen terlarut & $\mathrm{mg} / 1$ & Winkler & insitu & APHA (2005) \\
6 & Alkalinitas & $\mathrm{mg} / 1$ & Titrimetry & insitu & APHA (2005) \\
7 & Dayahantarlistrik & $\mu \mathrm{s} / \mathrm{cm}$ & Conductivity & Laboratory & APHA (2005) \\
8 & Nitrat $\left(\mathrm{N}-\mathrm{NO}_{3}\right)$ & $\mathrm{mg} / 1$ & Brusin Sulfate & Laboratory & Boyd $(1988)$ \\
9 & Ammonia $\left(\mathrm{N}^{\mathrm{N}} \mathrm{NH}_{3}\right)$ & $\mathrm{mg} / 1$ & Phenate & Laboratory & Boyd $(1988)$ \\
10 & FosforTotal $\left(\mathrm{TP}^{2}\right)$ & $\mathrm{mg} / 1$ & Ascorbic acid & Laboratory & Boyd $(1988)$ \\
11 & Orthofosfat $\left(\mathrm{PO}_{4}\right)$ & $\mathrm{mg} / 1$ & Ascorbic acid & Laboratory & Boyd $(1988)$ \\
12 & Khlorofil-a & $\mathrm{mg} / \mathrm{m} 3$ & Spektrofotometri & Laboratory & Boyd $(1988)$ \\
\hline
\end{tabular}

Untuk mengetahui distribusi dan hubungan parameter kualitas air dari stasiun penelitian digunakan analisa komponen utama/Principal Component Analysis $(P C A)$,yang sebelumnya data ditransformasikan dalam log (X+1) (Husnah et al., 2007 ; Uriarte \& Fernando, 2005). Data yang digunakan ini adalah nilai parameter perairan dari setiap stasiun penelitian untuk menilai kelayakan perairan bagi peruntukan kehidupan ikan. Analisa hubungan antar parameter dilakukan dengan uji-t pada korelasi matriks dengan signifikansi $\mathrm{p}<0,05$

Nilai indeks status trofik perairan danau dihitung dengan metode Carlson (1977) mengggunakan 3 parameter yaitu nilai kecerahan dari secchi disk $\left(\mathrm{TSI}_{\mathrm{SD}}\right)$, total fosfor

Tabel 2. Kategori status trofik perairan berdasarkan Indeks Status Trofik Carlson (1977)

Table 2. Water trophic state catagory based on the Trophic State Index'Carlson (1977)

\begin{tabular}{|c|c|c|}
\hline Skor & $\begin{array}{l}\text { Status Trofik / } \\
\text { Trophic Status }\end{array}$ & Keterangan / Remarks \\
\hline$<30$ & Ultraoligotrofik & Air jernih, konsentrasi oksigen terlarut tinggi sepanjang tahun \\
\hline $30-40$ & Oligotrofik & Air jernih, konsentrasi oksigen terlarut tinggi sampai sedang. \\
\hline $40-50$ & Mesotrofik & Kecerahan air sedang \\
\hline $50-60$ & Eutrofik ringan & Penurunankecerahan air, terjadi problem tanaman air \\
\hline $60-70$ & Eutrofik sedang & $\begin{array}{l}\text { Keadaan perairan didominasi oleh alga hijau-biru, terjadi } \\
\text { penggumpalan, problem tanaman air sudah ekstensif }\end{array}$ \\
\hline $70-80$ & Eutrofik berat & $\begin{array}{l}\text { Terjadi blooming algae, tanaman air membentuk lapisan bed seperti } \\
\text { kondisi hypereutrofik }\end{array}$ \\
\hline$>80$ & Hypereutrofik & $\begin{array}{l}\text { Terjadi gumpalan alga, ikan mati, tanaman air sedikit didominasi oleh } \\
\text { alga }\end{array}$ \\
\hline
\end{tabular}

$\left(\mathrm{TSI}_{\mathrm{TP}}\right)$, dan konsentrasi khlorofil-a $\left(\mathrm{TSI}_{\mathrm{Ch}}\right)$. Rumus index status trofik Carlson (Carlson's Trophic State Index, TSI) adalah sebagai berikut:

$$
\mathrm{TSI}=\left(\mathrm{TSI}_{\mathrm{SD}}+\mathrm{TSI}_{\mathrm{TP}}+\mathrm{TSI}_{\mathrm{Ch} I}\right) / 3 \text {, }
$$

Dimana : TSI $=$ Trophic State Index Carlson, $\mathrm{TSI}_{\mathrm{SD}}=60$ $-14,41 \mathrm{Ln}(\mathrm{SD})$; dalam meter, $\mathrm{TSI}_{\mathrm{TP}}=14,42 \mathrm{Ln}(\mathrm{TP})+4,15$; dalam $\mu \mathrm{g} / \mathrm{L}, \mathrm{TSI}_{\mathrm{Chl}}=30,6+9,81 \mathrm{Ln}(\mathrm{Chl}) ;$ dalam $\mu \mathrm{g} / \mathrm{L}$. Setelah nilai indeks diperoleh, nilai indeks dimasukkan kedalam kriteria status trofik perairan dari Carlson yang diklasifikasikan dalam tingkat kesuburan sangat rendah, rendah, sedang dan tinggi disajikan dalam Tabel 2.
Estimasi potensi produksi ikan dihitung dengan menggunakan persamaan yang dikemukakan Henderson \& Welcomme (1974) dalam Moreau \& De Silva (1991) yaitu:

$$
\mathrm{Y}=14,314 * \mathrm{MEI}^{0,4681}
$$

Dimana : $\mathrm{Y}=$ potensi produksi ikan (kg/ha/tahun), $\mathrm{MEI}=$ Morpho Edhaphic Index, yaitu besaran nilai DHL ( $\mu$ mhos/ $\mathrm{cm}$ ) dibagi dengan kedalaman rata-rata danau (meter). Kedalaman rata-rata diperoleh dari pengukuran bathimetri danau menggunakan alat hidroakustik.
Untuk mengetahui jumlah ikan dan udang ditangkap nelayan (tingkat pemanfaatan sumberdaya ikan dan udang) dilakukan survei ke pasar ikan di Kota Enarotali (Ibukota Kabupaten Paniai). Ikan dan udang yang dijual disajikan dalam bentuk tumpukan untuk satu tumpukan kecil beratnya antara $1-1,2 \mathrm{~kg}$ (rata-rata $1,1 \mathrm{~kg}$ ), sedangkan satu tumpukan besar beratnya antara 2-2,3 kg (rata-rata $2,15 \mathrm{~kg}$ ). Estimasi tingkat pemanfaatan atau produksi hasil tangkapan ikan dan udang dihitung berdasarkan jumlah tumpukan ikan dan udang yang dijual di pasar setiap harinya dilakukan oleh enumerator yang telah dipilih. 
Jumlah tumpukan yang telah dihitung, selanjutnya dikalikan dengan berat rata-ratanya. Estimasi tingkat pemanfaatan sumber daya ikan dan udang merupakan produksi hasil tangkapan ikan dan udang oleh para nelayan Danau Paniai.

\section{HASIL DAN BAHASAN Hasil}

Data hasil pengukuran kedalaman dan kecerahan air di setiap stasiun penelitian tertera pada Tabel 3 dan 4 . Pengukuran parameter fisika-kimia perairan secara stratifikasi di bagian permukaan, area pada batas kecerahan dan di bagian dasar perairan terdapat pada Lampiran 1, 2 dan 3 serta disajikan juga dalam bentuk grafik hasil analisis komponen utama (PCA) tertera pada Gambar 2, 3 dan 4. Hasil analisis komponen utama (PCA) pada parameter kualitas air Danau Paniai di bagian permukaan dengan menggunakan dua sumbu utama mampu menjelaskan $76.48 \%$ dari ragam total yang terdiri dari komponen satu sebesar $51,83 \%$ dan komponen kedua sebesar 24,65\%. Hal ini menunjukkan setiap stasiun pengamatan dapat dikelompokkan menurut karakter penciri habitatnya (Gambar 2). Kelompok pertama adalah stasiun Kali Aga (St.2), kelompok kedua stasiun Ibumu Maeda (St.1), kelompok ketiga stasiun hutan lindung (St.3), Obano (St.4), Pulau Kambing (St.5) dan Muara Awe (St.7), sedangkan kelompok keempat adalah stasiun Muara Dimea (St.6) (Gambar 2). Kelompok pertama dicirikan oleh sumbu I positif yaitu Fosfat, Total fosfor (TP), Nitrat, dan Amoniak, sedangkan pada kelompok kedua dicirikan pada sumbu II positif yaitu DHL dan Alkalinitas. Kelompok ketiga dicirikan pada sumbu I negatif dicirikan oleh $\mathrm{O}_{2}$ dan $\mathrm{pH}$, sedangkan kelompok empat dicirikan pada sumbu II negatif dominan dicirikan oleh Suhu (Gambar 2).

Tabel 3. Kedalaman perairan (meter) Danau Paniai tahun penelitian 2016

Table 3. Water depth of Paniai Lake (meter) research in the year of 2016

\begin{tabular}{lcccc}
\hline $\begin{array}{l}\text { Stasiun / } \\
\text { Stations }\end{array}$ & $\begin{array}{c}\text { April/ } \\
\text { April }\end{array}$ & $\begin{array}{c}\text { Juli/ } \\
\text { July }\end{array}$ & $\begin{array}{c}\text { Oktober/ } \\
\text { October }\end{array}$ & $\begin{array}{c}\text { Rerata/ } \\
\text { Mean }\end{array}$ \\
\hline 1= Ibumu Maeda (inlet) & 1.6 & 1.6 & 1.7 & 1.6 \\
2= Kali Aga (inlet) & 5.3 & 5.8 & 4.2 & 5.1 \\
3= dekathutanlindung & 27.6 & 32.0 & 33.9 & 31.2 \\
4= Obano (tengahdanau) & 44.0 & 45.0 & 48.5 & 45.8 \\
5= PulauKambing & 45.0 & 40.4 & 41.5 & 42.3 \\
6= MuaraDimea (inlet) & 6.0 & 6.0 & 6.3 & 6.1 \\
7= Muara Awe (outlet) & 8.3 & 8.4 & 8.4 & 8.4 \\
\hline Rerata / Mean & 19.7 & 19.9 & 20.6 & \\
\hline
\end{tabular}

Tabel 4. Kecerahan perairan (meter) Danau Paniai pada tahun penelitian 2016

Table 4. Water transparancy (meter) of Paniai Lake research in the year of 2016

\begin{tabular}{lcccc}
\hline $\begin{array}{l}\text { Stasiun / } \\
\text { Stations }\end{array}$ & $\begin{array}{c}\text { April/ } \\
\text { April }\end{array}$ & $\begin{array}{c}\text { Juli/ } \\
\text { July }\end{array}$ & $\begin{array}{c}\text { Oktober/ } \\
\text { October }\end{array}$ & $\begin{array}{c}\text { Rerata/ } \\
\text { Mean }\end{array}$ \\
\hline 1= Ibumu Maeda (inlet) & 1.6 & 1.6 & 1.7 & 1.6 \\
2= Kali Aga (inlet) & 1.6 & 1.5 & 0.9 & 1.3 \\
3= dekathutanlindung & 3.6 & 3.7 & 3.8 & 3.7 \\
4= Obano (tengahdanau) & 4.3 & 3.8 & 3.5 & 3.9 \\
5= PulauKambing & 4.0 & 3.9 & 3.5 & 3.8 \\
6= MuaraDimea (inlet) & 4.8 & 4.9 & 5.0 & 4.9 \\
7= Muara Awe (outlet) & 2.9 & 3.7 & 3.5 & 3.4 \\
\hline Rerata / Mean & 3.3 & 3.3 & 3.1 & \\
\hline
\end{tabular}

Di daerah batas kecerahan dengan menggunakan dua sumbu utama, mampu menjelaskan $69.76 \%$ dari ragam total yang terdiri dari komponen pertama sebesar $46,71 \%$ dan komponen kedua sebesar 23,05\%. Di daerah batas kecerahan juga ada 4 (empat) kelompok stasiun : Kelompok pertama adalah stasiun Kali Aga (St.2), kelompok kedua stasiun Ibumu Maeda (St.1), kelompok ketiga stasiun Pulau Kambing (St.5) dan Muara Dimea (St.6), dan kelompok keempat stasiun dekat hutan lindung (St.3), Obano (St.4), dan Muara Awe (St.7). Kelompok pertama dicirikan oleh sumbu I positif yaitu Fosfat, Total fosfor (TP), dan Amoniak, kelompok kedua dicirikan pada sumbu II positif yaitu DHL, Nitrat dan Alkalinitas. Kelompok ketiga dicirikan pada sumbu I negatif yaitu $\mathrm{O}_{2}, \mathrm{pH}$, dan Suhu (Gambar 3). 


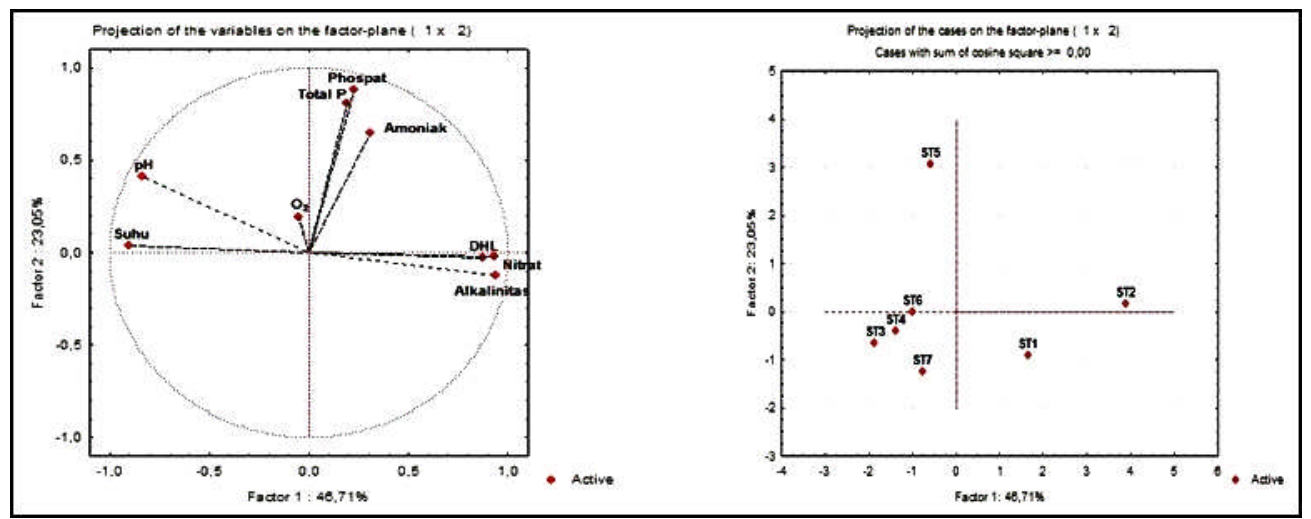

Gambar 2. Analisis komponen utama pada parameter kualitas air Danau Paniai di bagian permukaan.

Figure 2. Principal Component Analysis of the Lake Paniai's water quality parameters on the surface.

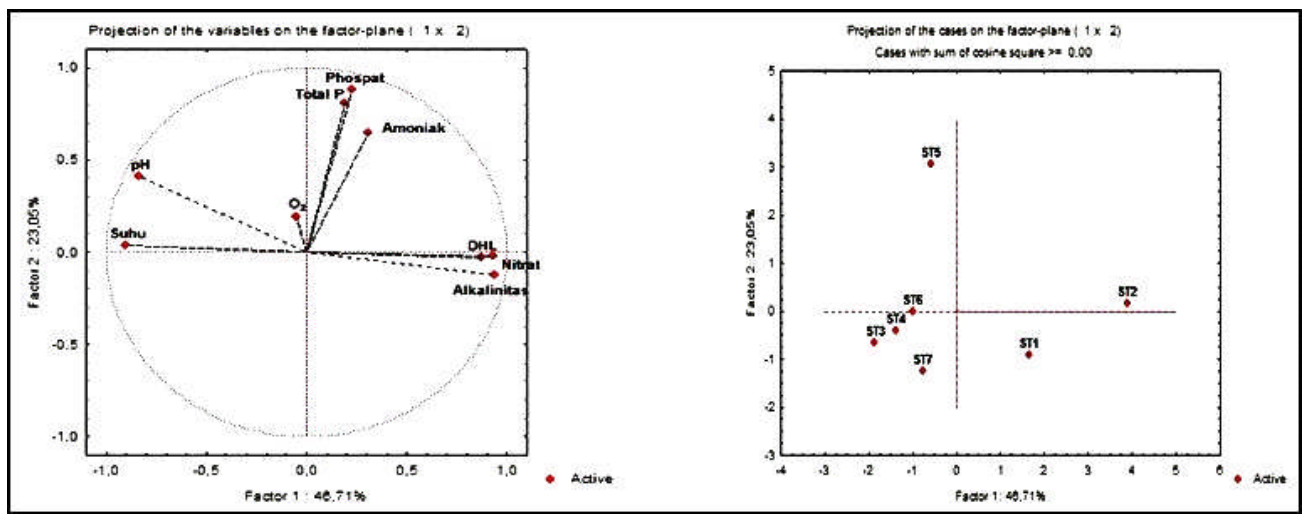

Gambar 3. Analisis komponen utama pada parameter kualitas air Danau Paniai di daerah batas kecerahan.

Figure 3. Principal Component Analysis of the Lake Paniai's water quality parameters at the brightness limit.

Di daerah bagian dasar perairan dengan menggunakan dua sumbu utama mampu menjelaskan $74.42 \%$ dari ragam total yang terdiri dari komponen pertama 54,46\% dan komponen kedua 19,96\%. Hasil analisis parameter kualitas air di daerah bagian dasar menunjukkan adanya empat kelompok stasiun yaitu: kelompok pertama adalah stasiun Kali Aga (St.2); kelompok kedua stasiun Ibumu Maeda (St.1), stasiun Muara Dimea (St.6), dan Muara Awe (St.7); kelompok ketiga adalah Obano (St.4) dan Pulau Kambing (St.5); dan kelompok keempat stasiun dekat hutan lindung (St.3). Kelompok pertama dicirikan oleh sumbu I positif yaitu $\mathrm{O}_{2}$, Alkalinitas, DHL dan Nitrat,kelompok kedua dicirikan oleh sumbu II positif yaitu Amoniak dan $\mathrm{pH}$. Kelompok ketiga dicirikan oleh sumbu I negatif dicirikan oleh Fosfat dan Total Fosfor (TP); sedangkan kelompok empat dicirikan sumbu II negatif yaitu Suhu (Gambar 4).

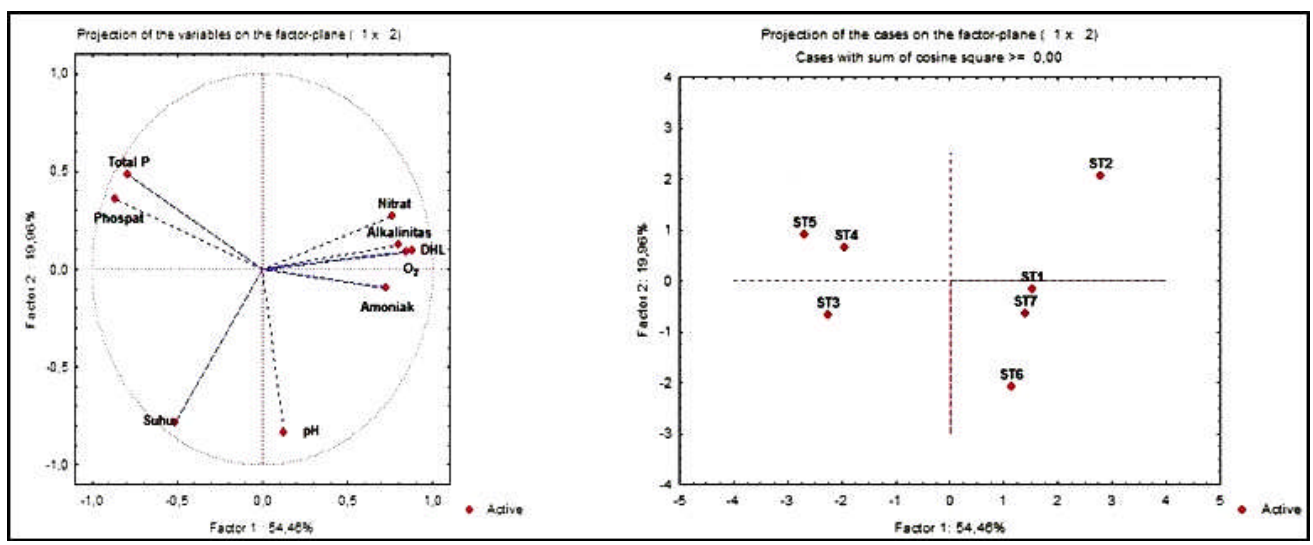

Gambar 4. Analisis komponen utama pada parameter kualitas air Danau Paniai di bagian dasar.

Figure 4. Principal Component Analysis of the Lake Paniai's water quality parameters at the bottom. 
Secara umum parameter kualitas air baik dari bagian permukaan, di daerah batas kecerahan dan pada bagian dasar yang mendominasi pada kelompok pertama adalah Stasiun Kali Aga (St.2) merupakan daerah inlet Danau Paniai dicirikan adanya Fosfat, Total fosfor (TP), Nitrat dan Amoniak. Kelompok kedua didominasi oleh stasiun Ibumu Maeda (St.1) merupakan daerah inlet Danau Paniai dicirikan adanya DHL dan Alkalinitas. Kelompok ketiga dijelaskan pada sumbu I negatif terdiri dari dua stasiun yang mendominasi dengan lokasi berdekatan yakni Obano (St.4) dan Pulau Kambing (St.5) merupakan wilayah tengah danau memiliki ciri parameter fisika kimia yang sama. Kedekatan antar stasiun ini disebabkan letaknya berdekatan di tengah Danau Paniai, ini terciri khusus pada parameter Oksigen terlarut dan $\mathrm{pH}$. Pergerakan kecepatan arus yang kuat menyebabkan pergerakan massa air teraduk secara sempurna sehingga kandungan oksigen terlarutnya meningkat (Wetzel, 1975). Kelompok keempat didominasi oleh stasiun dekat hutan lindung (St.3) yang dicirikan oleh Suhu. Suhu suatu perairan dipengaruhi oleh musim, lintang, waktu, sirkulasi udara, penutupan awan dan kedalaman (Effendie, 2003).

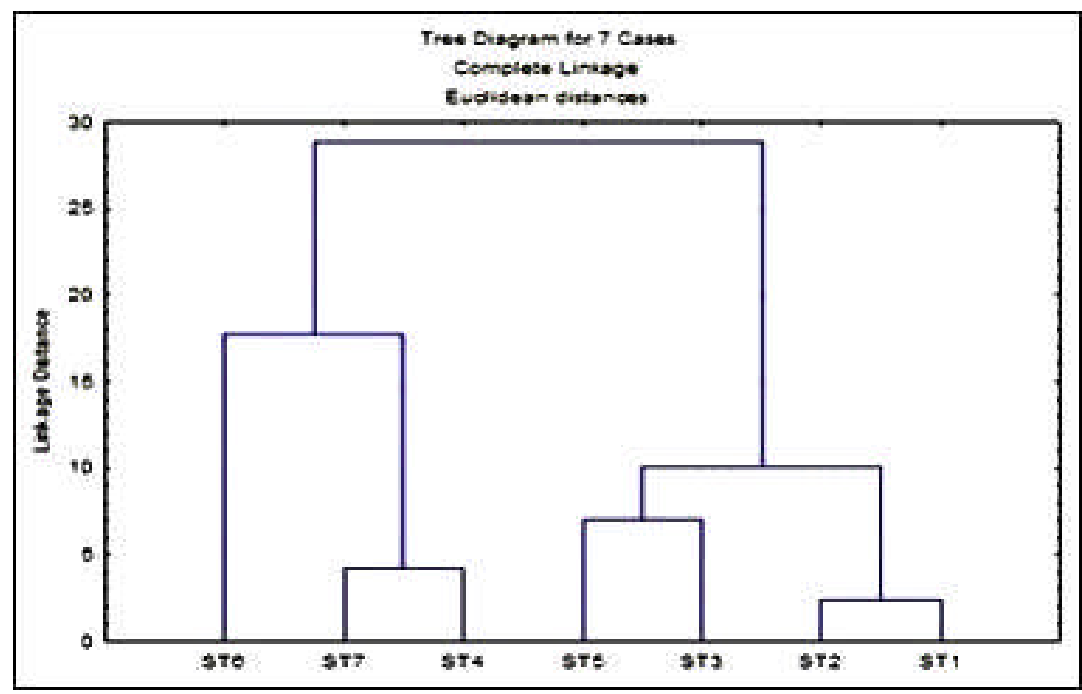

Gambar 5. Dendogram analisis kluster pengelompokkan stasiun berdasarkan tingkat kesuburan perairan.

Figure 5. Dendogram Cluster Analysis of grouping stations based on water productivity levels.

Dihubungkan antara tingkat kesuburan perairan dengan pengelompokan stasiun berdasarkan analisis kluster, ditemukan tren pola pengelompokan stasiun dalam 2 kategori (Gambar 5). Kelompok pertama, kategori eutrofik ringan mulai dari stasiun Ibumu Maeda (St.1), Kali Aga (St.2), perairan dekat hutan lindung (St.3) dan Pulau Kambing (St.5), daerah ini merupakan satu wilayah perairan yang tersebar dari dua inlet Danau Paniai yaitu
Ibumu Maeda dan Kali Aga hingga ke wilayah Pulau Kambing. Kelompok kedua, kategori mesotrofik mulai dari stasiun Obano (St.4), Muara Dimea (St.6) dan Muara Awe (St.7) merupakan bagian tengah ke arah hilir outlet Danau Paniai.

Estimasi tingkat kesuburan perairan dan potensi produksi ikan tertera pada Tabel 8 dan 9.

Tabel 8. Nilai Indeks Status trofik (TSI) perairan Danau Paniai tahun 2016

Table 8. Trophic State Index (TSI) Values of Paniai Lake waters in 2016

\begin{tabular}{cccccccccc}
\hline Bulan & St-1 & St-2 & St-3 & St-4 & St-5 & St-6 & St-7 & Rerata & Status Trofik \\
\hline April & 58 & 59 & 54 & 53 & 57 & 40 & 57 & 54 & Eutrofikringan \\
Juli & 48 & 46 & 51 & 41 & 55 & 39 & 42 & 46 & Mesotrofik \\
Oktober & 53 & 54 & 53 & 44 & 58 & 41 & 45 & 50 & Eutrofikringan \\
\hline Rerata & 53 & 53 & 53 & 46 & 56 & 40 & 48 & 50 & Eutrofikringan \\
\hline
\end{tabular}


Tabel 9. Nilai potensi produksi ikan (kg/ha/tahun) Danau Paniai, 2016 Table 9. Values of fish production potential (kg/ha/year) of Paniai Lake, 2016

\begin{tabular}{lcccc}
\hline \multicolumn{1}{c}{$\begin{array}{c}\text { Stasiun / } \\
\text { Stations }\end{array}$} & $\begin{array}{c}\text { April/ } \\
\text { April }\end{array}$ & $\begin{array}{c}\text { Juli/ } \\
\text { July }\end{array}$ & $\begin{array}{c}\text { Oktober/ } \\
\text { October }\end{array}$ & $\begin{array}{c}\text { Rerata/ } \\
\text { Mean }\end{array}$ \\
\hline 1=Ibumu Maeda (inlet) & 35.6 & 38.9 & 25.5 & 33.3 \\
2=Kali Aga (inlet) & 33.9 & 39.9 & 26.2 & 33.3 \\
3=Alami (dekathutanlindung) & 32.5 & 39.2 & 22.4 & 31.4 \\
4=Obano (tengahdanau) & 33.2 & 38.9 & 23.8 & 32.0 \\
5=PulauKambing (tengahdanau) & 34.1 & 39.6 & 23.5 & 32.4 \\
6=Muara Dimea (inlet D. Tage) & 33.9 & 39.0 & 23.8 & 32.2 \\
7=Muara Awe (outlet) & 35.1 & 38.7 & 23.7 & 32.5 \\
\hline Rerata/ Mean & 34.0 & 39.2 & 24.1 & 32.4 \\
\hline
\end{tabular}

Untuk selanjutnya hasil estimasi tingkat pemanfaatan sumberdaya ikan/udang yang direfleksikan dari data produksi hasil tangkapan nelayan di Danau Paniai adalah sebagai berikut : Data yang diperoleh pada jumlah tumpukan udang cherax yang dijual ke pasar rata-rata ada 596 tumpukan per bulan, untuk ikan rata-rata ada 568 tumpukan per bulan. Tumpukan kecil beratnya antara 1$1,2 \mathrm{~kg}$ (rata-rata $1,1 \mathrm{~kg}$ ), tumpukan besar beratnya antara $2-2,3 \mathrm{~kg}$ (rata-rata $2,15 \mathrm{~kg}$ ). Perbandingan jumlah tumpukan kecil: tumpukan besar $=2: 1$. Dari data tersebut, selanjutnya dihitung jumlah tumpukan dari masing-masing jenis (udang dan ikan) sebagai berikut: 1). Jumlah tumpukan kecil udang cherax adalah (2/3)x596= 397 tumpukan per bulan dan jumlah tumpukan besar udang cherax adalah 596-397= 199 tumpukan per bulan. 2). Jumlah tumpukan kecil untuk jenis ikan adalah (2/3)x568=379 tumpukan per bulan dan jumlah tumpukan besar adalah 568-379= 189 tumpukan per bulan.

\section{Bahasan}

Kedalaman danau pada area perairan bagian tengah yaitu di stasiun-4 (Obano) berkisar 44-48,5 meter, rata-rata 45,8 meter (Tabel 3). Kedalaman terendah di stasiun1(Ibumu Maeda) dan stasiun-2(Kali Aga) yang merupakan inlet pada bagian litoral danau. Lokasi/titik kedalaman tertinggi ada di stasiun-4 (Obano) yaitu $\pm 47,6$ meter. Kecerahan terendah ada di stasiun-1 dan 2, kecerahan tertinggi di stasiun-3, 4 dan 6 (Tabel 4). Stasiun 1 dan 2 mempunyai nilai kecerahan air rendah karena stasiun ini merupakan daerah litoral danau, perairannya dangkal dan di sekitarnya terdapat aktivitas pemanfaatan lahan (pemukiman, penggalian tanah, pasar dan pelabuahan) yang memungkinkan terjadinya pemasukan partikelpartikel koloid organik dan anorganik ke perairan yang menyebabkan nilai kecerahan air rendah. Danau Paniai dengan rerata kecerahan air 3,1-3,3 meter (Tabel 4), mengklasifikasikan perairan danau pada tingkat kesuburan sedang/ mesotrofik (Carlson, 1977).

Dari analisa komponen utama, secara vertikal perairan danau dapat dibagi atas 3 bagian yaitu: bagian produktif (lapisan permukaan), lapisan kedua (batas kecerahan dan lapisan ketiga (bagian dasar danau). Ketiga bagian ini mempunyai nilai indeks kesuburan berbeda sesuai dengan karakter penciri habitat masing-masing. Dihubungkan dengan parameter kualitas air, pada bagian produktif dicirikan oleh cukupnya kandungan fosfat, total fosfor dan nitrat.

Rerata suhu air $22,2^{\circ} \mathrm{C}$ di bagian permukaan, $22,1^{\circ} \mathrm{C}$ di daerah batas kecerahan dan $21,5^{\circ} \mathrm{C}$ di bagian dasar. Penurunan suhu dari permukaan sampai ke dasar tidak signifikan sehingga tidak terbentuk lapisan termoklin (Wetzel, 1975). Perubahan suhu berpengaruh terhadap proses fisika, kimia, dan biologi badan air (Effendi, 2003). Perubahan suhu air di setiap kelompok stasiun berfluktuasi kecil sehingga tidak berpengaruh pada dinamika kehidupan organisme air termasuk juga pada kesuburan perairannya. Merujuk pada kriteria baku mutu air untuk perikanan (Peraturan Pemerintah R I, No. 82, 2001; NTAC, 1968; Pescod, 1973; Ahmad, 1992; Aisyah \& Subehi, 2012), perairan danau termasuk perairan yang baik untuk kehidupan ikan.Nilai DHL berkisar dari 179 sampai 187 $\mu \mathrm{mhos} / \mathrm{cm}$, menunjukkan kondisi perairan relatif masih baik bagi kehidupan ikan (Kartamihardja, 1987). Nilai ini bila dibandingkan dengan danau yang mengandung mineral tinggi seperti Danau Batur yang mempunyai nilai DHL diatas $2500 \mu \mathrm{mhos} / \mathrm{cm}$ (Samuel et al., 2011), maka Danau Paniai digolongkan mempunyai perairan berkadar mineral rendah, tetapi masih tergolong normal untuk perairan alami apabila mengacu kepada rentang nilai yang dikemukakan Boyd (1988) yaitu 20-1500 $\mu \mathrm{mhos} / \mathrm{cm}$. Dalam perairan lunak (soft waters), ikan dapat mentolerir DHL yang berkisar 150-500 $\mu \mathrm{mhos} / \mathrm{cm}$ (Ellis dalam Sylvester, 1958). Nilai DHL berkaitan erat dengan jumlah ion mineral yang terlarut dalam perairan, semakin tinggi jumlah ion terlarut, nilai DHL perairan semakin tinggi (Rizki et al., 2015). Nilai DHL terkait pula dengan konsentrasi total dari kation dan anion perairan. Air tawar yang mempunyai nilai DHL lebih dari 1000 ìmhos/cm, terindikasi perairan tercemar atau perairan menerima jumlah run off yang besar dari tanah(Tessema et al., 2014). PH perairan danau diatas 7 kecuali di bagian dasar pH-nya 6,97. Secara vertikal, $\mathrm{pH}$ 
perairan cenderung menurun dengan bertambahnya kedalaman (Adiansyah et al., 2016). Nilai pH tersebut masih mendukung kehidupan ikan secara wajar (Wardoyo, 1979).

Rerata nilai oksigen terlarut $5,60 \mathrm{mg} / \mathrm{L}$ di bagian permukaan, 5,49 $\mathrm{mg} / \mathrm{L}$ di daerah perairan pada batas kecerahan dan 3,69 mg/L di bagian dasar. Kadar oksigen terlarut pada zona fotik (permukaan sampai batas kecerahan) diatas $5 \mathrm{mg} / \mathrm{L}$ dan di lapisan dasar 3,69 mg/L, secara general masih tergolong baik untuk mendukung kehidupan organisme air secara normal termasuk kehidupan ikan dan udang (Peraturan Pemerintah RI, No. 82, 2001 ; Jeffries \& Mills, 1996 ; Swingle, 1968 ; Odum, 1996 ; Ahmad, 1992).

Untuk parameter alkalinitas, nilainya berkisar 79-81 mg/ L, mengklasifikasikanperairan Danau Paniai masuk dalam klasifikasi tingkat kesuburan rendah. (Swingle, 1968). Kadar nitrat 0,272 mg/L (permukaan), 0,291 mg/L (di daerah batas kecerahan) dan $0,341 \mathrm{mg} / \mathrm{L}$ (pada bagian dasar), mengklasifikasikan perairan pada tingkat kesuburan sedang(Wetzel, 1975 ; Effendi, 2003). Kadar ammonia 0,096 $\mathrm{mg} / \mathrm{L}$ (permukaan), 0,155 mg/L (batas kecerahan) dan 0,131 $\mathrm{mg} / \mathrm{L}$ (bagian dasar), mengklasifikasikan perairan dalam kisaran aman untuk kehidupan ikan (Pescod, 1973 ; Redner, 1978 dalam Arthana, 2009 dan Peraturan Pemerintah No.
20, 1990). Kadar fosfat berkisar 0,036-0,107 mg/L, tergolong perairan dengan tingkat kesuburan sedang-tinggi (Vollenweider dalam Wetzel, 1975). Kadar total fosfor (TP) 0,093 mg/L (permukaan), 0,108 mg/L (batas kecerahan) dan 0,181 mg/L (bagian dasar), nilai reratanya $0,127 \mathrm{mg} / \mathrm{L}$ termasuk perairan dengan tingkat kesuburan tinggi (Effendi, 2003).

Pada Tabel 8, nilai Indeks Status Trofik (TSI) perairan berdasarkan waktu penelitian (temporal) berkisar 45-54 (meso-eutrofik) dan berdasarkan stasiun penelitian (spasial)berkisar 40-56 (meso-eutrofik). Berdasarkan pada keseluruhan data, nilai indeksnya sebesar 49 dalam klasifikasi tingkat kesuburan sedang (mesotrofik). Dibandingkan dengan danau-danau lain di Indonesia (Tabel 10), kesuburan perairan Danau Paniai sebanding dengan perairan Danau Diatas dan Danau Dibawah, lebih rendah dibandingkan dengan Danau Singkarak, Batur, Lindu dan Kerinci. Perairan danau dengan tingkat kesuburan tinggi disebabkan adanya bahan hara (nutrien) yang berasal dari aktivitas pertanian disekitar danau banyak masuk kedalam perairan danau ketika musim hujan, contohnya Danau Batur dan Danau Kerinci. Untuk Danau Paniai, aktivitas pertanian dekat danau jumlahnya masih sedikit sehingga jumlah bahan hara yang masuk ke badan air danau tidak banyak sehingga tingkat kesuburan perairan sedang.

Tabel 10. Nilai indeks dan status trofik perairan Danau Paniai serta 6 danau lain di Indonesia Table 10. Index value and trophic status of Paniai Lake and 6 other lakes in Indonesia

\begin{tabular}{clccll}
\hline No & \multicolumn{1}{c}{ Nama Danau } & $\begin{array}{c}\text { Tipe } \\
\text { Danau }\end{array}$ & Nilai TSI & Status Trofik & \multicolumn{1}{c}{ Sumber Referensi } \\
\hline 1 & Danau Paniai & Tektonik & 49 & Mesotrofik & Penelitian ini (2016) \\
2 & Danau Singkarak & Tektonik & 51 & Eutrofik ringan & Suryono, et al. $(2008)$ \\
3 & Danau Batur & Vulkanik & 61 & Eutrofik sedang & Samuel \& Suryati (2014) \\
4 & Danau Lindu & Tektonik & 53 & Eutrofik ringan & Samuel, et al. $(2014)$ \\
5 & Danau Kerinci & Tektonik & 62 & Eutrofik sedang & Samuel, et al. (2015) \\
6 & Danau Diatas & Tektonik & 42 & Mesotrofik & Samuel \& Adiansyah (2016) \\
7 & Danau Dibawah & Tektonik & 41 & Mesotrofik & Adiansyah, et al. $(2017)$ \\
\hline
\end{tabular}

Hasil estimasi potensi produksi ikan, angkanya berkisar $31,4-33,3 \mathrm{~kg} / \mathrm{ha} /$ tahun dan rata-rata $32,4 \mathrm{~kg} / \mathrm{ha} / \mathrm{tahun}$ (Tabel 9). Angka potensi produksi sebesar $32,4 \mathrm{~kg} / \mathrm{ha} / \mathrm{tahun}$ termasuk sesuai dengan kesuburan perairan danau yang mempunyai tingkat kesuburan sedang. Dengan luas perairan danau $15.130 \mathrm{Ha}$, diperoleh angka potensi produksi sebesar 475-504 ton/tahun dan rata-rata 491 ton/ tahun. Angka potensi produksi ikan sebesar 32,4 kg/ha/ tahun masih dibawah angka potensi produksi ikan untuk danau-danau di Indonesia yang besarannya $88 \mathrm{~kg} / \mathrm{ha} /$ tahun (Kartamihardja et al., 2010).

Pemanfaatan sumberdaya ikan yang dihitung dari hasil tangkapan nelayan, diperoleh jumlah tumpukan udang dan ikan yang dijual di pasar berjumlah \pm 596 tumpukan per bulan (untuk udang cherax) dan untuk ikan \pm 568 tumpukan per bulan. Tumpukan kecil berat rata-rata 1,1 $\mathrm{kg}$ dan tumpukan besar berat rata-rata 2,15 kg. Berdasarkan jumlah tumpukan ikan dan udang tersebut, didapatkan bahwa hasil tangkapan udang cherax oleh nelayan dari Danau Paniai dalam satu tahun ada sebesar 10374,6 kg/ tahun dibulatkan 10,4 ton/tahun, Untuk ikan sebesar 9879 $\mathrm{kg} /$ tahun dibulatkan menjadi 9,9 ton/tahun. Jumlah hasil tangkapan total (udang+ikan) di Danau Paniai adalah $10,4+9,9=20,3$ ton/tahun. Bila rerata potensi produksi ikan di Danau Paniai ada 491 ton/tahun, berarti tingkat pemanfaatan sumberdaya udang+ikan di danau ini baru mencapai angka $(20,3 / 491) \times 100 \%=4,13 \%$, suatu angka pemanfaatan sumberdaya ikan+udang yang masih rendah dibandingkan dengan angka potensi produksinyanya. 


\section{KESIMPULAN}

Perairan Danau Paniai tergolong perairan yang baik dan ideal untuk mendukung kehidupan organisme air termasuk ikan dan udang. Status trofik perairan berada pada tingkatan mesotrofik yaitu mempunyai tingkat kesuburan sedang dengan nilai indeks sebesar 49. Angka potensi produksi ikan sebesar 32,4 kg/ha/tahun atau 491 ton/tahun tergolong kecil. Hasil tangkapan ikan dan udang oleh para nelayan (tingkat pemanfaatan) ada sebesar 20,3 ton/tahun atau sebesar $4,13 \%$ dari angka potensi produksinya, diartikan tingkat pemanfaatan sumberdaya ikan dan udang di Danau Paniai rendah. Disarankan masih perlu penambahan jumlah alat tangkap atau jumlah nelayan dalam melakukan aktifitas penangkapan ikan dan udang di danau. Namun demikian, aktivitas penangkapan dengan cara-cara yang tidak ramah lingkungan seperti penggunaan putas dan stroom harus tetap menjadi pertimbangan dalam opsi-opsi pengelolaan sumberdaya ikan dan udang di Danau Paniai.

\section{PERSANTUNAN}

Tulisan ini merupakan kontribusi dari kegiatan riset "Karakteristik habitat, potensi dan biologi ikan di Danau Paniai, Papua", tahun 2016. Penulis mengucapkan terima kasih kepada Kepala BRPPUPP yang telah memberikan kepercayaan melakukan riset di danau ini. Kepada rekanrekan satu team penelitian yang telah membantu riset di lapangan, penulis mengucapkan terima kasih atas partisipasinya.

\section{DAFTAR PUSTAKA}

Adiansyah, V., Samuel, Ditya, Y.C., Mentari, R.D.P., Mersi., \& Yeimo, M. (2016). Karakteristik habitat, potensi dan biologi ikan di Danau Paniai (p. 162). Laporan Hasil Penelitian Balai Penelitian Perikanan Perairan Umum, Palembang.

Adiansyah, V., Samuel., \& Atminarso, D. (2017). Status trofik dan potensi produksi ikan di Danau Dibawah, Sumatera Barat. Prosiding Seminar Nasional Tahunan XIV, Hasil Penelitian Perikanan dan Kelautan, 22 Juli 2017, UGM Yogyakarta. p. 217-226.

Ahmad, T. (1992). Pengelolaan mutu air untuk budidaya ikan (p. 41). Balai Penelitian Perikanan Budidaya Pantai. Badan litbang Pertanian, Departemen Pertanian, Jakarta.

Aisyah, S., \& Subehi, L. (2012). Pengukuran dan Evaluasi Kualitas Air dalam Rangka Mendukung Pengelolaan Perikanan di Danau Limboto. Prosiding Seminar Nasional Limnologi VI. Pusat Penelitian LimnologiLIPI.
American Public Health Association (APHA). (2005). Standard Methods for The Examination of Water and Wastewater, $21^{\text {st }}$ edition. American Public Health Association, Washington, D. C.

Arthana, I.W., Suarna, I.W., \& Adnyana, I.W.S. (2009). Kondisi Ekosistem Danau-Danau di Provinsi Bali. Prosiding Konferensi Nasional Danau Indonesia I, Jilid 2. Bali. Kementerian Lingkungan Hidup. p. 268283.

Boyd, C.E. (1988). Water Quality in Warmwater fishponds (p. 359). Auburn University, Depart. Of Fisheries and Alied Aquaculture. First Edition, Alabama, USA.

Carlson, R.E. (1977). A trophic state index for lakes. Limnol. Oceanogr. V.22 (2), 361-369.

Effendi, H. (2003). Telaah kualitas air bagi pengelolaan sumber daya dan lingkungan perairan, Cetakan Kelima. Kanisius. Yogyakarta.

Husnah, Prianto, E., \& Aida, S.N. (2007). Kualitas perairan Sungai Musi bagian hilir ditinjau dari karakteristik fisika-kimia dan struktur komunitas makrozoobenthos. J.Lit.Perikan.Ind. Pusat Riset Perikanan Tangkap. 13(3), 167-177. DOI: http://dx.doi.org/10.15578/ jppi.13.3.2007.167-177

Jeffries, M., \& Mills, D. (1996). Freshwater ecology. Principles and Applications, John Wiley and Sons, Chicester United Kingdom.

Kartamihardja, E.S. (1987). Potensi produksi dan pengelolaan perikanan di Danau Toba, Sumatera Utara. Bulletin Penelitian Perikanan Darat, Bogor, 6(1), 6577.

Kartamihardja, E.S., Purnomo, K., Tjahjo, D.W.H., Umar, C., Sunarno, M.T.D., \& Koeshendrajana, S. (2010). Pemulihan Sumberdaya Ikan di Perairan Umum Daratan (p. 72). Petunjuk Teknis. Pusat Penelitian Pengelolaan Perikanan dan Konservasi Sumber Daya Ikan. Balitbang KP, Jakarta.

Kartikasari, S.N., Marshall, A.J., \& Beehler, B.M. (2012). Ekologi Pариа. Yayasan Pustaka Obor Indonesia dan Conservation Internasional. Jakarta

Kementerian Pekerjaan Umum, (2012). Buku Informasi Statistik Pekerjaan Umum.

Moreau, J., \& De Silva, S. S. (1991). Predictive fish yield models for lakes and reservoirs of the Philippines, Sri Lanka and Thailand. FAO Fisheries Technical Paper. 
NTAC. (1968). Water Quality Criteria (p. 234), FWPAC. Washington DC.

Odum, E. P. (1996). Dasar-Dasar Ekologi (p. 697). Samingan,T. dan Srigondono, B (Penterjemah). UGM Press, Yogyakarta.

Peraturan Pemerintah Republik Indonesia. (2001). Peraturan Pemerintah Republik Indonesia No. 82, Tahun 2001 tentang Pengelolaan Kualitas Air dan Pengendalian Pencemaran Air. Kementerian Lingkungan Hidup. Jakarta.

Pescod, M.B. (1973). Investigation of rational and effluent and stream standards for tropical countries (p. 59). AIT, Bangkok.

Rizki, A., Yunasfi., \& Muhtadi, A. (2015). Analisis Kualitas Air dan Beban Pencemaran di Danau Pondok Lapan, Salapian Kabupaten Langkat. Program studi Manajemen Sumber daya Perairan, Fakultas Pertanian, Universitas Sumatera Utara, Medan.

Samuel, Subagdja, Suryati, N.K., Adiansyah, V., Arisna, D., Hifni, T., \& Pamungkas, Y.P. (2011). Karakteristik Lingkungan, Biologi Ikan dan Potensi Pengembangan Perikanan di Danau Batur, Bali (p. 109). Laporan Teknis Penelitian. Balai Penelitian Perikanan Perairan Umum Palembang.

Samuel \& Suryati, N.K. (2014). Variasi kualitas air dan estimasi potensi produksi ikan perairan Danau Batur, Propinsi Bali. J. Lit. Perikan. Ind. 20(2), 89-96. DOI: http://dx.doi.org/10.15578/jppi.20.2.2014.89-96

Samuel, N. K. Suryati., \& Adiansyah, V. (2014). Karakteristik perairan dan potensi produksi ikan di Danau Lindu, Sulawesi Tengah. Prosiding Seminar Nasional Tahunan XI, Hasil Penelitian Perikanan dan Kelautan, UGM. 30 Agustus 2014, Yogyakarta. p. 143-152.

Samuel, Suryati, N. K., \& Adiansyah, V. (2015). Limnological condition and estimation of potential fish production of Kerinci Lake Jambi, Sumatera. I. Fish. Res. Ind, 21(1), 9-18. DOI: http://dx.doi.org/10.15578/ ifrj.21.1.2015.9-18

Samuel., \& Adiansyah, V. (2016). Kualitas air, status trofik dan potensi produksi ikan Danau Diatas, Propinsi Sumatera Barat. J. Lit. Perikan. Ind, 22(2), 83-94. DOI: http://dx.doi.org/10.15578/jppi.22.2.2016.83-94

Suryono, T., Sulawesty, F., Sunanisari, S., Cynthia, Triyanto, H., Haryani, G.S., Aji, G.S., Toruan, R.L., Tarigan, T., Yoga, G.P., Ridwansyah, I., Nomosatryo, S., Mardiati, Y., Maulana, E., \& Rosidah. (2008). Kajian pengembangan karakteristik limnologis perairan darat di Indonesia. Laporan Teknis 2008. Program Penguatan Kelembagaan Iptek, Pusat Penelitian Limnologi LIPI, Cibinong.

Swingle, H. (1968). Standardization of chemical analysis for waters and pond muds. FAO Fisheries Report, 44(4), 397-406.

Sylvester, R.O. (1958). Water Quality Studies in the Columbia River Basin (p. 133). US Departement Interior, Washington DC.

Tessema, A., Muhammed, A., Birhanu, T., \& Negu, T. (2014). Assessment of Physico-chemical Water Quality of Bira Dam Bati Wereda Amhara Region Ethiopia. Jurnal Aquaculture Research and Development. 5(6), 1-4. DOI: $10.4172 / 2155-9546.1000267$.

Uriarte, I. \& Fernando, V. (2005). Difference in Abundance and distribution of Copepods in two Estuaries of Bascque Coast (Bay of Biscay) in relation to pollution. Journal of Plankton Researh, 27 (9), 863-874. https:// doi.org/10.1093/plankt/fbi059.

Wardoyo, S.T.H. (1979). Kriteria kualitas air untuk keperluan pertanian dan perikanan (p. 41). Pusat Studi Pengelolaan Sumberdaya dan Lingkungan, IPB, Bogor.

Wetzel, R. G. (1975). Limnology (p. 743). W. B. Sauders Co. Philadelphia, Pennsylvania. 
Lampiran 1. Data parameter fisika-kimia perairan Danau Paniai bulan April 2016 Apendix 1. Physico-chemical water parameter data of Lake Paniai in April 2016

a. Secara In-situ

\begin{tabular}{|c|c|c|c|c|c|c|c|c|}
\hline Stasiun & Stratifikasi & $\begin{array}{c}\text { Secchi } \\
(\mathrm{m})\end{array}$ & $\begin{array}{c}\text { Depth } \\
(\mathbf{m})\end{array}$ & $\begin{array}{c}\text { Temp } \\
\operatorname{air}\left({ }^{\circ} \mathrm{C}\right)\end{array}$ & $\begin{array}{c}\text { DHL } \\
(\mu \mathrm{mhos} / \mathrm{cm})\end{array}$ & pH & $\begin{array}{c}\mathrm{CO}_{2} \\
(\mathrm{mg} / \mathrm{L})\end{array}$ & $\begin{array}{r}\mathrm{DO} \\
(\mathrm{mg} / \mathrm{I} \\
\end{array}$ \\
\hline 1 & Permukaan & 1,6 & 1,6 & 24,4 & 220 & 6,89 & 1,232 & 4,13 \\
\hline \multirow[t]{2}{*}{2} & Permukaan & 1,5 & 5,3 & 21,1 & 197 & 6,90 & 0,57 & 5,64 \\
\hline & Dasar & & & 20,6 & 183 & 6,48 & 0,792 & 5,44 \\
\hline \multirow[t]{3}{*}{3} & Permukaan & 3,6 & 27,6 & 25,1 & 189 & 7,51 & 0,352 & 6,04 \\
\hline & Bts. Kecerahan & & & 24,9 & 170 & 7,48 & 0,484 & 5,03 \\
\hline & Dasar & & & 24,3 & 165 & 7,22 & 0,572 & 2,92 \\
\hline \multirow[t]{6}{*}{4} & Permukaan & 4,3 & 44,0 & 25,5 & 190 & 7,47 & 0,44 & 5,13 \\
\hline & Bts. Kecerahan & & & 25,3 & 166 & 7,72 & 0,66 & 6,14 \\
\hline & $10 \mathrm{~m}$ & & & 24,9 & & & & 6,04 \\
\hline & $20 \mathrm{~m}$ & & & 24,6 & & & & 4,93 \\
\hline & $30 \mathrm{~m}$ & & & 24,1 & & & & 1,91 \\
\hline & Dasar & & & 23,9 & 194 & 6,31 & 1,584 & 1,81 \\
\hline \multirow[t]{3}{*}{5} & Permukaan & 4,0 & 45,0 & 25,5 & 203 & 7,57 & 0,44 & 5,13 \\
\hline & Bts. Kecerahan & & & 25,3 & 190 & 7,81 & 0,44 & 6,14 \\
\hline & Dasar & & & 23,9 & 188 & 6,52 & 1,76 & 1,81 \\
\hline \multirow[t]{2}{*}{6} & Permukaan & 4,8 & 6,0 & 25,7 & 201 & 7,74 & 0,44 & 5,54 \\
\hline & Dasar & & & 25,9 & 179 & 7,80 & 0,44 & 5,54 \\
\hline \multirow[t]{3}{*}{7} & Permukaan & 2,9 & 8,3 & 25,4 & 203 & 7,51 & 0,528 & 6,04 \\
\hline & Bts. Kecerahan & & & 25,5 & 209 & 7,19 & 0,528 & 5,94 \\
\hline & Dasar & & & 25,2 & 206 & 7,00 & 0,66 & 5,44 \\
\hline
\end{tabular}

b. Secara Ex-situ

\begin{tabular}{ccccccccc}
\hline Stasiun & Stratifikasi & $\begin{array}{c}\text { T. Alkali } \\
(\mathbf{m g} / \mathbf{L})\end{array}$ & $\begin{array}{c}\text { T. Hardness } \\
(\mathbf{m g} / \mathbf{L})\end{array}$ & $\begin{array}{c}\mathbf{N O}-\mathbf{N} \\
(\mathbf{m g} / \mathbf{L})\end{array}$ & $\begin{array}{c}\mathbf{N H}_{\mathbf{3}}-\mathbf{N} \\
(\mathbf{m g} / \mathbf{L})\end{array}$ & $\begin{array}{c}\mathbf{T . P O}_{\mathbf{4}} \\
(\mathbf{m g} / \mathbf{L})\end{array}$ & $\begin{array}{c}\mathbf{O} . \mathbf{P O} \\
(\mathbf{m g} / \mathbf{L})\end{array}$ & $\begin{array}{c}\mathbf{T S S} \\
(\mathbf{m g} / \mathbf{L})\end{array}$ \\
\hline 1 & Permukaan & 100 & 112 & 0,392 & 0,001 & 0,160 & 0,090 & - \\
2 & Permukaan & 83 & 86 & 1,216 & 0,038 & 0,285 & 0,122 & - \\
& Dasar & 86 & 97 & 0,863 & 0,173 & 0,217 & 0,135 & - \\
3 & Permukaan & 72 & 89 & 0,412 & 0,124 & 0,213 & 0,124 & - \\
& Bts. Kecerahan & 76 & 118 & 0,314 & 0,009 & 0,051 & 0,018 & - \\
& Dasar & 88 & 88 & 0,157 & 0,001 & 0,381 & 0,257 & - \\
4 & Permukaan & 75 & 83 & 0,412 & 0,134 & 0,240 & 0,078 & - \\
& Bts. Kecerahan & 76 & 83 & 0,294 & 0,013 & 0,018 & 0,078 & - \\
& Dasar & 87 & 88 & 0,098 & 0,073 & 0,411 & 0,275 & - \\
5 & Permukaan & 73 & 112 & 0,314 & 0,078 & 0,290 & 0,161 & - \\
& Bts. Kecerahan & 75 & 86 & 0,373 & 0,030 & 0,025 & 0,165 & - \\
& Dasar & 83 & 87 & 0,373 & 0,035 & 0,373 & 0,248 & - \\
& Permukaan & 84 & 96 & 0,216 & 0,036 & 0,019 & 0,002 & - \\
7 & Dasar & 82 & 93 & 0,157 & 0,001 & 0,011 & 0,202 & - \\
& Permukaan & 77 & 84 & 0,667 & 0,003 & 0,199 & 0,126 & - \\
& Bts. Kecerahan & 74 & 83 & 0,412 & 0,002 & 0,189 & 0,103 & - \\
& Dasar & 79 & 88 & 1,294 & 0,007 & 0,275 & 0,140 & - \\
\hline
\end{tabular}


Lampiran 2. Data parameter fisika-kimia perairan Danau Paniai bulan Juli 2016

Apendix 2. Physico-chemical water parameter data of Lake Paniai in July 2016

a. Secara In-situ

\begin{tabular}{|c|c|c|c|c|c|c|c|c|}
\hline Stasiun & Stratifikasi & $\begin{array}{c}\text { Secchi } \\
\text { (m) }\end{array}$ & $\begin{array}{c}\text { Depth } \\
(\mathbf{m})\end{array}$ & $\begin{array}{c}\text { Temp } \\
\operatorname{air}\left({ }^{\circ} \mathrm{C}\right)\end{array}$ & $\begin{array}{c}\text { DHL } \\
(\mu \mathrm{mhos} / \mathrm{cm})\end{array}$ & pH & $\begin{array}{c}\mathrm{CO}_{2} \\
(\mathrm{mg} / \mathrm{L})\end{array}$ & $\begin{array}{c}\mathrm{DO} \\
(\mathrm{mg} / \mathrm{L})\end{array}$ \\
\hline 1 & Permukaan & 1,6 & 1,6 & 21,5 & 662 & 6,74 & 1,23 & 4,13 \\
\hline \multirow[t]{2}{*}{2} & Permukaan & 1,5 & 5,8 & 15,6 & 257 & 6,74 & 1,06 & 6,24 \\
\hline & Dasar & & & 15,6 & 282 & 6,70 & 1,10 & 6,34 \\
\hline \multirow[t]{3}{*}{3} & Permukaan & 3,7 & 32,0 & 21,0 & 258 & 7,37 & 0,53 & 5,94 \\
\hline & Bts. Kecerahan & & & 21,7 & 259 & 7,22 & 0,66 & 5,74 \\
\hline & Dasar & & & 22,2 & 263 & 6,85 & 0,97 & 3,72 \\
\hline \multirow[t]{6}{*}{4} & Permukaan & & & 21,5 & 268 & 7,33 & 0,53 & 6,24 \\
\hline & Bts. Kecerahan & 3,8 & 45,0 & 21,6 & 241 & 7,36 & 0,44 & 6,04 \\
\hline & $10 \mathrm{~m}$ & & & 21,4 & & & & 4,03 \\
\hline & $20 \mathrm{~m}$ & & & 20,7 & & & & 2,52 \\
\hline & $30 \mathrm{~m}$ & & & 20,6 & & & & 2,72 \\
\hline & Dasar & & & 20,3 & 289 & 6,59 & 1,50 & 2,01 \\
\hline \multirow[t]{3}{*}{5} & Permukaan & 3,9 & 40,4 & 22,2 & 259 & 7,29 & 0,57 & 5,44 \\
\hline & Bts. Kecerahan & & & 22,0 & 253 & 7,25 & 0,53 & 5,44 \\
\hline & Dasar & & & 21,1 & 260 & 6,82 & 0,57 & 4,83 \\
\hline \multirow[t]{2}{*}{6} & Permukaan & 4,9 & 6,0 & 21,0 & 240 & 7,05 & 0,66 & 4,93 \\
\hline & Dasar & & & 21,0 & 273 & 6,95 & 0,66 & 4,93 \\
\hline \multirow[t]{3}{*}{7} & Permukaan & 3,7 & 8,4 & 21,1 & 257 & 7,01 & 0,53 & 6,04 \\
\hline & Bts. Kecerahan & & & 21,5 & 253 & 7,05 & 0,53 & 5,94 \\
\hline & Dasar & & & 20,0 & 252 & 6,95 & 0,66 & 5,74 \\
\hline
\end{tabular}

a. Secara Ex-situ

\begin{tabular}{|c|c|c|c|c|c|c|c|c|}
\hline Stasiun & Stratifikasi & $\begin{array}{c}\text { T. Alkali } \\
\text { (mg/L) }\end{array}$ & $\begin{array}{c}\text { T. } \\
\text { Hardness } \\
(\mathrm{mg} / \mathrm{L})\end{array}$ & $\begin{array}{l}\mathrm{NO}_{3}-\mathrm{N} \\
(\mathrm{mg} / \mathrm{L})\end{array}$ & $\begin{array}{l}\mathrm{NH}_{3}-\mathrm{N} \\
(\mathrm{mg} / \mathrm{L})\end{array}$ & $\begin{array}{c}\mathrm{T.PO} \\
(\mathrm{mg} / \mathrm{L})\end{array}$ & $\begin{array}{l}\mathrm{O} \mathrm{PO}_{4} \\
(\mathrm{mg} / \mathrm{L})\end{array}$ & $\begin{array}{c}\text { TSS } \\
(\mathrm{mg} / \mathrm{L})\end{array}$ \\
\hline 1 & Permukaan & 81 & 108 & 0,33 & 0,16 & 0,071 & 0,001 & 0,744 \\
\hline \multirow[t]{2}{*}{2} & Permukaan & 88 & 95 & 0,50 & 0,31 & 0,026 & 0,002 & 2,430 \\
\hline & Dasar & 88 & 100 & 0,41 & 0,22 & 0,089 & 0,070 & \\
\hline \multirow[t]{3}{*}{3} & Permukaan & 75 & 82 & 0,01 & 0,03 & 0,126 & 0,004 & 1,739 \\
\hline & Bts. Kecerahan & 76 & 83 & 0,01 & 0,19 & 0,126 & 0,004 & \\
\hline & Dasar & 75 & 84 & 0,23 & 0,09 & 0,198 & 0,129 & \\
\hline \multirow[t]{3}{*}{4} & Permukaan & 76 & 79 & 0,09 & 0,15 & 0,013 & 0,007 & 0,748 \\
\hline & Bts. Kecerahan & 76 & 79 & 0,21 & 0,26 & 0,013 & 0,005 & \\
\hline & Dasar & 75 & 84 & 0,27 & 0,10 & 0,101 & 0,061 & \\
\hline \multirow[t]{3}{*}{5} & Permukaan & 76 & 82 & 0,01 & 0,01 & 0,013 & 0,003 & 1,869 \\
\hline & Bts. Kecerahan & 77 & 80 & 0,12 & 0,30 & 0,459 & 0,151 & \\
\hline & Dasar & 70 & 85 & 0,16 & 0,13 & 0,473 & 0,174 & \\
\hline \multirow[t]{2}{*}{6} & Permukaan & 76 & 82 & 0,01 & 0,08 & 0,012 & 0,003 & 0,280 \\
\hline & Dasar & 76 & 82 & 0,16 & 0,28 & 0,012 & 0,003 & \\
\hline \multirow[t]{3}{*}{7} & Permukaan & 75 & 83 & 0,09 & 0,06 & 0,013 & 0,004 & 0,930 \\
\hline & Bts. Kecerahan & 76 & 83 & 0,18 & 0,05 & 0,016 & 0,004 & \\
\hline & Dasar & 78 & 83 & 0,26 & 0,16 & 0,017 & 0,004 & \\
\hline
\end{tabular}


Lampiran 3. Data parameter fisika-kimia perairan Danau Paniai, Oktober 2016 Apendix 3. Physico-chemical water parameter data of Lake Paniai in October 2016

a. Secara In-situ

\begin{tabular}{|c|c|c|c|c|c|c|c|c|c|}
\hline Stasiun & Stratifikasi & & $\begin{array}{l}\text { Secchi } \\
(\mathrm{m})\end{array}$ & $\begin{array}{c}\text { Depth } \\
\text { (m) }\end{array}$ & $\begin{array}{c}\text { Temp } \\
\text { air }\left({ }^{\circ} \mathrm{C}\right)\end{array}$ & $\begin{array}{c}\text { DHL } \\
(\mu \mathrm{mhos} / \mathrm{cm})\end{array}$ & pH & $\begin{array}{c}\mathrm{CO}_{2} \\
(\mathrm{mg} / \mathrm{L})\end{array}$ & $\begin{array}{c}\text { DO } \\
(\mathrm{mg} / \mathrm{L})\end{array}$ \\
\hline 1 & Permukaan & & 1,7 & 1,7 & 20,3 & 101 & 7,30 & 1,54 & 4,93 \\
\hline \multirow[t]{2}{*}{2} & Permukaan & & 0,9 & 4,2 & 16,9 & 132 & 7,37 & 0,97 & 6,64 \\
\hline & Dasar & & & & 16,4 & 91 & 7,32 & 1,10 & 4,53 \\
\hline \multirow[t]{3}{*}{3} & Permukaan & & 3,8 & 33,9 & 22,2 & 85 & 7,72 & 0,02 & 6,44 \\
\hline & Bts. Kecerahan & & & & 21,2 & 63 & 7,45 & 0,02 & 5,84 \\
\hline & Dasar & & & & 21,1 & 88 & 7,38 & 0,88 & 1,21 \\
\hline \multirow[t]{6}{*}{4} & Permukaan & & 3,5 & 48,5 & 22,8 & 91 & 7,72 & 0,22 & 5,54 \\
\hline & Bts. Kecerahan & & & & 22,5 & 86 & 7,53 & 0,22 & 4,63 \\
\hline & $10 \mathrm{~m}$ & & & & 22,4 & & & & 5,64 \\
\hline & $20 \mathrm{~m}$ & & & & 21,8 & & & & 3,62 \\
\hline & $30 \mathrm{~m}$ & & & & 21,1 & & & & 1,61 \\
\hline & Dasar & & & & 21,1 & 87 & 7,26 & 3,52 & 1,41 \\
\hline \multirow[t]{3}{*}{5} & Permukaan & & 3,5 & 41,5 & 22,4 & 86 & 7,77 & 0,18 & 5,84 \\
\hline & Bts. Kecerahan & & & & 22,2 & 87 & 7,50 & 0,26 & 5,23 \\
\hline & Dasar & & & & 21,1 & 92 & 7,26 & 0,70 & 1,91 \\
\hline \multirow[t]{2}{*}{6} & Permukaan & & 5,0 & 6,3 & 22,2 & 88 & 7,82 & 0,00 & 5,54 \\
\hline & Dasar & & & & 22,2 & 89 & 7,50 & 0,22 & 5,54 \\
\hline \multirow[t]{3}{*}{7} & Permukaan & & 3,5 & 8,4 & 22,4 & 87 & 7,77 & 0,22 & 6,04 \\
\hline & Bts. Kecerahan & & & & 22,7 & 87 & 7,36 & 0,22 & 5,74 \\
\hline & Dasar & & & & 21,0 & 92 & 7,28 & 0,88 & 5,44 \\
\hline \multicolumn{10}{|c|}{ a. Secara Ex-situ } \\
\hline Stasiun & Stratifikasi & $\begin{array}{c}\text { T. Alkal } \\
\text { (mg/L) }\end{array}$ & & $\begin{array}{l}\text { Hardness } \\
(\mathrm{mg} / \mathrm{L})\end{array}$ & $\begin{array}{l}\mathrm{NO}_{3}-\mathrm{N} \\
(\mathrm{mg} / \mathrm{L})\end{array}$ & $\begin{array}{l}\mathrm{NH}_{3}-\mathbf{N} \\
(\mathrm{mg} / \mathrm{L})\end{array}$ & $\begin{array}{l}\text { T.PO4 } \\
(\mathrm{mg} / \mathrm{L})\end{array}$ & $\begin{array}{l}\mathrm{O} \mathrm{PO}_{4} \\
(\mathrm{mg} / \mathrm{L})\end{array}$ & $\begin{array}{c}\text { TSS } \\
(\mathrm{mg} / \mathrm{L}) \\
\end{array}$ \\
\hline 1 & Permukaan & 81 & & 108 & 0,33 & 0,16 & 0,071 & 0,001 & 0,744 \\
\hline \multirow[t]{2}{*}{2} & Permukaan & 88 & & 95 & 0,50 & 0,31 & 0,026 & 0,002 & 2,430 \\
\hline & Dasar & 88 & & 100 & 0,41 & 0,22 & 0,089 & 0,070 & \\
\hline \multirow[t]{3}{*}{3} & Permukaan & 75 & & 82 & 0,01 & 0,03 & 0,126 & 0,004 & 1,739 \\
\hline & Bts. Kecerahan & 76 & & 83 & 0,01 & 0,19 & 0,126 & 0,004 & \\
\hline & Dasar & 75 & & 84 & 0,23 & 0,09 & 0,198 & 0,129 & \\
\hline \multirow[t]{3}{*}{4} & Permukaan & 76 & & 79 & 0,09 & 0,15 & 0,013 & 0,007 & 0,748 \\
\hline & Bts. Kecerahan & 76 & & 79 & 0,21 & 0,26 & 0,013 & 0,005 & \\
\hline & Dasar & 75 & & 84 & 0,27 & 0,10 & 0,101 & 0,061 & \\
\hline \multirow[t]{3}{*}{5} & Permukaan & 76 & & 82 & 0,01 & 0,01 & 0,013 & 0,003 & 1,869 \\
\hline & Bts. Kecerahan & 77 & & 80 & 0,12 & 0,30 & 0,459 & 0,151 & \\
\hline & Dasar & 70 & & 85 & 0,16 & 0,13 & 0,473 & 0,174 & \\
\hline \multirow[t]{2}{*}{6} & Permukaan & 76 & & 82 & 0,01 & 0,08 & 0,012 & 0,003 & 0,280 \\
\hline & Dasar & 76 & & 82 & 0,16 & 0,28 & 0,012 & 0,003 & \\
\hline \multirow[t]{3}{*}{7} & Permukaan & 75 & & 83 & 0,09 & 0,06 & 0,013 & 0,004 & 0,930 \\
\hline & Bts. Kecerahan & 76 & & 83 & 0,18 & 0,05 & 0,016 & 0,004 & \\
\hline & Dasar & 78 & & 83 & 0,26 & 0,16 & 0,017 & 0,004 & \\
\hline
\end{tabular}

